\title{
Pengembangan Buku Ajar IPA Kelas VI untuk Siswa Sekolah Dasar
}

\author{
Anita Hidayati, Rufi'i, Yoso Wiyarno
}

(C) 2020 JEMS (Jurnal Edukasi Matematika dan Sains)

This is an open access article under the CC-BY-SA license (https://creativecommons.org/licenses/bysa/4.0/) ISSN 2337-9049 (print), ISSN 2502-4671 (online)

\begin{abstract}
Abstrak:
Penelitian ini bertujuan untuk mengembangkan buku teks yang dapat digunakan untuk mendukung kegiatan pembelajaran IPA Kelas 6 di SDN Sambungrejo Sukodono. Penelitian ini menggunakan model pengembangan Dick dan Carey. Subjek uji coba penelitian adalah 50 siswa dan seorang guru di sekolah. Instrumen pengumpulan data yang digunakan adalah pedoman wawancara, lembar validasi ahli untuk dosen dan praktisi pendidikan Hasil penelitian mengungkapkan bahwa tingkat kelayakan buku teks sains untuk semester pertama dilihat dari penilaian dosen ahli, pengawas sekolah, kepala sekolah, guru kelas dan penilaian siswa berdasarkan pada setiap aspek penilaian termasuk aspek kelayakan isi konten mendapatkan rerata skor 4,086 dengan predikat "baik" dan persentase tingkat kesesuaian sebesar 81,7\%; aspek kelayakan presentasi mendapat rerataskor sebesar 4,307 dengan predikat "sangat baik" dan persentase tingkat kelayakan sebesar $86,1 \%$; pada kelayakan bahasa, mendapatkan rerata skor 4,388 dengan predikat "sangat baik" dengan tingkat kesesuaian 87,75\%; Sedangkan pada aspek grafis diperoleh rerata skor 4,302 dengan predikat "sangat baik" dengan tingkat kesesuaian $86 \%$. Jadi dapat disimpulkan bahwa pengembangan buku teks sains secara keseluruhan memperoleh rerata skor 4,271 dengan predikat "baik" dan tingkat persentase tingkat kelayakannya $85,54 \%$. Dengan demikian, buku ini dinyatakan layak digunakan.
\end{abstract}

Kata Kunci: Pengembangan; Buku Ajar; Pembelajaran IPA; Sekolah Dasar

\section{Abstract:}

The purpose of this research was to develop a coursebook that can be used to support the activities of Science learning of the first semester at Grade 6 of SDN Sambungrejo Sukodono. The research used the development model of Dick and Carey. The subjects of research trials were 50 students and a teacher at the school. The instruments for data collection utilized were the interview, the sheet of expert validation for lecturers and practitioners of education, assessment from expert lecturers, school superintendent, principal, classroom teacher and students. The research results revealed that the eligibility level of the science coursebook based on each aspect of the assessment including feasibility aspects of content obtained an average score 4.086 as "good" category with the level of appropriateness of $81.7 \%$; feasibility aspect of presentation gets an average score of 4.307 as "very good" category with $86.1 \%$ eligibility level; on the feasibility of the language, earning an average score of 4.388 "very good" category with the level of appropriateness of $87.75 \%$; While on the graphic aspects it obtained an average score 4.302 as "very good" category with the level of appropriateness of $86 \%$. To conclude, the science coursebook for the first semester and the sixth grade students overall gained an average score 4.271 with "good" category and level eligibility $85.54 \%$. Thus, this book statedfeasibility.

Keywords: Development; Coursebook;;Science Learning, Primary School level.

\section{Pendahuluan}

Buku teks pelajaran adalah salah satu sumber belajar yang paling sering digunakan dalam

Anita Hidayati, Universitas PGRI Adi Buana Surabaya

ahidayati825@gmail.com

Rufi'i, Universitas PGRI Adi Buana Surabaya

rufii@unipasby.ac.id

Yoso Wiyarno, Universitas PGRI Adi Buana Surabaya

yoso.wiyarno@gmail.com 

sumber

kegiatan pembelajaran di kelas. Buku ajar juga digunakan sebagai bahan ajar sekaligus

belajar bagi siswa yang bersifat konvensional (Rohani, 1997). Namun meskipun buku teks tergo-

long konvensional dan sering menganggap tradisional, namun buku teks masih cukup mampu dalam memberikan sumbangsih yang besar pada kegiatan pembelajaran di sekolah (Hamalik, 1994). Tidak jarang ada beberapa materi pelajaran yang tidak dapat diajarkan tanpa bantuan buku teks.

Ada banyak sekali penerbit yang mengeluarkan buku teks. Esensi dari buku teks pelajaran adalah memberikan materi sekaligus informasi tambahan terkait dengan pembelajaran kepada peserta didik melalui bahan cetak (BPSDMP-PMP, 2012). Buku teks pelajaran tidak hanya berisi materi pembelajaran namun juga dilengkapi dengan berbagai informasi yang relevan secara lengkap dan menyeluruh, sehingga penggunaan buku teks pelajaran ini dapat digunakan secara berdampingan baik dengan media pembelajaran maupun tanpa media pembelajaran (Prastowo 2012:12)

Loveridge dkk. (1987) menjelaskan bahwa buku teks berisi materi dan bahan-bahan pendukung yang telah diseleksi pada mata pelajaran tertentu dan tersusun secara sistematis. Pusat Perbukuan (2006: 1) menjelaskan bahwa buku teks merupakan buku pegangan bagi peserta didik pada jenjang dan mata pelajaran tertentu yang digunakan sebagai media pembelajaran yang bersifat pengajaran. Dari dua definisi tentang buku teks diatas dapat disimpulkan bahwa buku teks pelajaran adalah buku sekolah yang dijadikan pegangan oleh peserta didik dalam menunjang kegiatan pembelajaran pada mata pelajaran jenjang pendidikan tertentu, dimana fungsi utamanya adalah sebagai sumber belajar dan menggali kemampuan kognitif peserta didik.

Tujuan dari mata pelajaran Ilmu Pengetahuan Alam di SD/MI adalah untuk memahami berbagai konsep Sains dan manfaatnya dalam kehidupan sehari-hari serta berfungsi untuk melanjutkan ke jenjang pendidikan yang lebih tinggi (Depdiknas, 2003: 27; Samatowa, 2006).

Fungsi dari mata pelajaran IPA juga dijelaskan dalam Sumaji (2006:35) antara lain (1) Memberikan bekal pengetahuan dasar bagi peserta didik yang akan melanjutkan pendidikan ke jenjang berikutnya serta untuk diterapkan dalam kehidupan sehari-hari, (2) Menerapkan konsep dasar IPA serta mengembangkannya melalui berbagai keterampilan, (3) Menanamkan kepada peserta didik sikap ilmiah serta menggunakan metode ilmiah dalam pemecahan masalah, (4) Mendorong siswa untuk mencintai dan mengagungkan Pencipta-Nya melalui kesadaran siswa dalam melestarikan alam beserta isinya, (5) Memunculkan inovasi dan kreatifitas siswa, (6) Meningkatkan pemahamanpeserta didik akan adanya gagasan atau 
informasi baru dalam bidang IPTEK, (7) Mengembangkan minat peserta didik terhadapsains.

Buku teks pelajaran yang ada saat ini tidak mampu menyajikan ketiga unsur yang ada yaitu produk, proses ilmiah dan pemupukan sikap. Di SDN Sambungrejo, khususnya di kelas VI buku teks yang dipakai pada mata pelajaran IPA adalah BSE yang dicetak oleh penerbit. Namun penulis sekaligus sebagai guru kelas VI merasa isi dari buku teks tersebut kurang lengkap, hal tersebut didasarkan pada analisis standart kompetensi dan kompetesi dasar IPA kelas VI SD. Selain itu kebijakan di SDN Sambungrejo dalam meningkatkan aktivitas belajar siswa adalah dengan mengadakan buku LKS (lembar kerja siswa) yang dibeli dari penerbit tertentu. Materi dalam LKS tentunya sangat terbatas, sehingga dibutuhkan buku sumber untuk membantu siswa dalam mengerjakan LKS. Selain itu penulis juga menyebarkan angket kebutuhan akan buku ajar kepada 50 peserta didik kelas VI di SDN Sambungrejo. Dari hasil angket tersebut didapatkan data ada 40 anakdari 50 anak atau 80\% peserta didik menyatakan membutuhkan buku ajar IPA selain BSE. Dari segi kelengkapan isi buku BSE didapatkan data ada 38 anak dari 50 anak atau 76 \% menyatakan buku BSE kurang lengkap. Dari sinilah kemudian penulis berkeinginan untuk mengembangkan buku ajar IPA kelas VI semser I berdasarkan model pengembangan Dick and Carey(2001).

Model R\&D Dick Carey adalah pendekatan prosedural yang dikembangkan oleh Walter Dick, Lou Carey, dan James O. Carey dalam The Systematic Design of Instruction(2001). Selanjutnya model tersebut lebih dikenal dengan nama model pengembangan Dick and Carey. Model pengembangan Dick and Carey memberikan saran agar desain pengembangannya dilakukan secara runtut. Pemaparan tahap-tahap penelitian pada model pengembangan Dick and Carey dilakukan secara deskriptif. Secara umum tahapan dalam penelitian ini terdiri atas tiga bagian yakni tahap pertama adalah pra-pengembangan, tahap kedua adalah pengembangan, dan tahap ketiga adalah pasca-pengembangan. Model pengembangan Dick and Carey menetapkan metodologi untuk merancang instruksi berdasarkan model reduksionis yaitu memecah instruksi menjadi komponen yang lebih kecil. Secara khusus target instruksi terdapat pada keterampilan dan pengetahuan yang akan diajarkan serta menjadikan kondisi sesuai hasil yang diinginkan.

Ada beberapa penelitian yang telah mengembangkan bahan ajar IPA di tingkat sekolah dasar. Diantaranya adalah Fitriya dan Indriyeni (2017), Pratiwi (2016) Fauziah (2015), dan Sukerni (2014). Penelitian-penelitian tersebut meliputi pengembangan bahan ajar berbasis masalah, berbasis pembelajaran kontekstual, dan pembelajaran terpadu untuk tema tertentu, dan berbasis model Dick and Carey. Penelitian-penelitian tersebut hanya mengutamakan atau terfokus pada tema dan konteks tertentu.

Berangkat dari kenyataan di atas, penelitian ini bertujuan untuk mengembangkan bahan ajar IPA untuk kelas VI dengan menggunakan model pengembangan Dick and Carey dengan kecukupan materi dalam bahan ajar untuk mencapai kompetensi seperti yang diharapkan di SDN Sambungrejo.

\section{Metode}

Penelitian ini merupakan penelitian pengembangan atau disebut dengan development 
research yang bertujuan untuk menghasilkan sebuah produk tertentu, dan sekaligus menguji efektifitas produk yang dihasilkan. Borg and Gall (dalam Sugiyono, 2011: 4) menyatakan bahwa penelitian pengembangan adalah sebuah proses untuk mengembangkan serta memvalidasi produk yang digunakan dalam dunia pendidikan dan kegiatan pembelajaran. Penelitian ini dilakukan di SDN Sambungrejo semester 1 tahun pelajaran 2017/2018. Subjek Penelitian adalah siswa kelas enam tahun pelajaran2017/2018.

Instrumen merupakan alat bantu dalam pengumpulan data penelitian dengan menggunakan metode tertentu. Penelitain ini menggunakan tiga instrumen yaitu instrumen untuk studi pendahuluan, validasi ahli materi dan guru, serta angket penilaian siswa terhadap buku ajar. Jenis data yang digunakan adalah deskripsi kuantitatif, dimana data tersebut berasal dari hasil wawancara guru, lembar validitas uji ahli dan guru, serta lembar penilaian siswa.

Jenis data yang diperoleh dari penelitian ini dapat dikelompokkan menjadi dua bentuk, yaitu data kualitatatif dan kuantitatif. Data kualitatif diperoleh dari hasil wawancara yang dilakukan pada tahap pengumpulaninformasi serta dari komentar dan saran yang diberikan oleh dosen ahli, guru dan siswa dalam angket kelayakan buku ajar IPA Kelas VI SD, sedangkan data kuantitatif diperoleh dari skor angket penilaian kualitas buku ajar IPA Kelas VI SD yang diberikan oleh dosen ahli, guru dan siswa.

Tahap terakhir adalah menganalisis semua data yang telah terkumpul. Data yang diperoleh melaui instrumen angket dianalisis dengan teknik statistik deskriptif.Data yang diperoleh melalui instrumen pedoman wawancara lisan diubah menjadi bentuk verbal yang berupa transkrip hasil wawancara, kemudian data yang diperoleh dari instrumen angket dianalisis dengan teknik statistik deskriptif.

\section{Hasil dan Pembahasan}

Sebelum dilakukan pengembangan pada buku IPA Kelas VI Semster 1 maka diawali dengan melakukan studi pendahuluan dengan melibatkan siswa kelas VI dan guru kelas VI di SDN Sambungrejo guna memperoleh informasi dan menganalisis kebutuhan di lapangan. Pengumpulan informasi selanjutnya diperoleh dari hasil wawancara dengan guru dan siswa kelas VI SDN Sambung rejo, Kepala Sekolah SDN Sambungrejo serta Pengawas Sekolah dasar di wilayah kecamatan sukodono adalah tahap awal pengembangan buku ajar IPA kels VI ini. Wawancara tersebut bertujuan untuk mengetahui sejauh mana penggunaan buku teks pelajaran IPA Kelas VI semester I yang disediakan oleh sekolah melalui perpustakaan sekolah.

Berdasarkan hasil wawancara dengan guru kelas 6, kepala sekolah dan pengawas sekolah, bahwa sumber belajar yang ada di SDN Sambungrejo sangat terbatas. Hal itu disebabkan oleh banyak faktor, antara lain kebijakan kurikulim yang berubah-ubah, kebijakan penggunaan dana bos dan pengelolaan perpustakaan. Sehingga pengembangan buku ajar IPA Kleas VI ini akan memberikan banyak manfaat bagi kegiatanpembelajaran.

Setelah dilakukan studi pendahuluan didapatkan informasi bahwasannya pengembangan buku ajar IPA kelas VI dirasa perlu, langkah selanjutnya dalam pengembangan buku ajar ini adalah merencanakan pembuatan buku. Tahapan yang akandilakukan dalam pembuatan buku ajar ini adalah menentukan tujuan, pengumpulan bahan seperti materi dari berbagai referensi dan menyusun kerangka buku sesuai model yang dipilih. Tujuan akhir 
penyususnan buku ajar ini yaitu dapat meningkatkan pengetahuan dan keluasanmateri pada mata pelajaran IPA kelas VI semester 1.

Hasil validasi dosen ahli, Pengawas sekolah, Kepala Sekolah dan teman sejawat serta penilaian siswa menunjukkan bahwa buku ajar IPA Kelas VI SD/MI yang dikembangkan dinyatakan layak karena mendapat predikat baik. Hasil validasi dosen ahli materi menunjukkan nilai rerata skor yang diperoleh dari hasil validasi produk sebelum direvisi atau tahap 1 sebesar 3,54 dengan kategori "baik". Kesimpulan sementara adalah Buku ajar IPA Kelas VI SD/MI semester 1 yang dikembangkan sudah baik, namun masih harus disempurnakan pada beberapaaspek.

Setelah dilakukan revisi, terdapat peningkatan skor yang signifikan pada seluruh aspek sebesar 4,58 dengan predikat"sangat baik". Hal ini menunjukkan bahwa kualitas buku yang diuji pada tahap 2 atau hasil revisi lebih baik dari sebelumnya. Rerata skor keseluruhan aspek hasil validasi ahli materi tahap 1 dan 2 adalah 4,06 dengan tingkat kelayakan baik atau layak. Hal ini berarti menurut dosen ahli, buku yang dikembangkan sudah tergolong layak. Hasil validasi Pengawas Sekolah, kepala sekolah danguru kelas VI menunjukkan nilai rata-rata skor yang diperoleh guru kelas pada seluruh aspek adalah 4,140 dengan kategori "baik", nilai ratarata skor yang diperoleh kepala sekolah pada seluruh aspek adalah 4,100 dengan predikat "baik", dan nilai rata-rata skor yang diperoleh pengawas sekolah pada seluruh aspek adalah 3,975 dengan kategori "baik". Validasi oleh guru kelas, kepala sekolah dan pengawas sekolah hanya dilakukan satu kali. Hal tersebut dikarenakan guru merupakan reviewer dan praktisi pendidikan, bukan sebagai ahli materi sehingga cukup dengan satu kali validasi. Kesimpulan hasil rata-rata skor keseluruhan dari ketiga praktisi pendidikan tersebut adalah 4,071 dengan tingkat kelayakan baik atau layak. Hal ini berarti menurut pengawas sekolah, kepala sekolah dan guru kelas VI, buku yang dikembangkan sudah tergolong layak dan dapat dipergunakan untuk keperluan pembelajaran di kelas. Hasil penilaian siswa pada tabel 17 menunjukkan bahwa skor rata-rata keseluruhan penilaian dari keempat aspek adalah 4,132 dengan tingkat kelayakan baik atau layak. Penilaian dari siswa ini bertujuan untuk mengetahui bagaimana respon siswa terhadap buku yang dikembangkan. Hasil penilaian dari keempat aspek menunjukkan siswa sebagai pengguna memiliki ketertarikan dengan buku tersebut. Hal ini berarti buku yang dikembangkan sudah tergolonglayak.

Tingkat kelayakan semua aspek penilaian berdasarkan hasil validasi dosen ahli, pengawas sekolah, kepala sekolah, guru kelas VI, dan penilaian siswa pada tabel 18 menunjukkan bahwa buku dinyatakan layak untuk digunakan. Aspek-aspek dinilai layak apabila dari rata-rata skor yang didapatkan memiliki kategori minimal“cukup".

Buku ajar minimal terdiri dari tiga bagian yaitu bagian awal yang memuat pendahuluan seperti bahan ajar pada umumnya, yakni halaman cover, halaman judul, kata pengantar, pendahuluan, dan daftar isi . Pada bagian isiterdiri dari lima kegiatan pembelajaran yaitu materi, latihan dan uji pemahaman. Bagian akhir terdiri dari glosarium, daftar pustaka serta sumber artikel dan gambar (Kurniasih, 2014:71-72).

Penyajian materi pembelajaran dalam buku ajar IPA yang dikembangkan ini mengacu pada empat landasan penulisan buku pelajaran menurut pusat perbukuan Depdiknas (2006:7) dan Muslich(2010:134-170). Empat landasan tersebut meliputi: landasan ilmu pengetahuan 
alam, landasan ilmu pendidikan dan keguruan, landasan kebutuhan peserta didik, dan landasan bahasa yang digunakan. Bahasa yang digunakan dalam pengembangan buku ajar IPA kelas VI SD/MI semester 1 dikembangkan ini sesuai dengan landasan bahasa yang dikemukakan oleh (Muslich, 2010:303). Bahasa yang digunakan harus mudah dipahami, lugas dengan kosakata, frase, singkat, dan jelas serta mampu memberi kemudahan bagi siswa untuk memahami setiap pelajaran yang disajikan. Pafa aspek kegrafikan hanya dibatasi pada kesesuaian ukuran format buku, penggunaan huruf, kemenarikan sampul,desain isi buku, ilustrasi, dan kualitascetakan.

Kekonsistensi sistematika penulisan buku ini ditunjukkan pada setiap bab yang memuat uraian materi, kesimpulan, dan evaluasi. Kelayakan buku ajar yang dikembangkan dalam penelitian ini ditentukan dengan nilai minimal " $C$ " atau berpredikat "cukup". Seperti yang telah diuraikan pada bab sebelumnya, nilai " $C$ " berada pada rentang skor 2,6 $<X<3,4$ dengan presentase $41-60 \%$. Dalam penelitian ini, skor yang diperoleh berdasarkan penilaian dosen ahli, pengawas sekolah, kepala sekolah, guru kelas VI, dan respon siswa adalah $\mathrm{X}>3,4$ atauberkategori" baik" dengannilai“ $B$ ”. Rata-rata yang diperoleh dariseluruh validator pada semua aspek adalah 4,271 atau berada dalam kategori "sangat baik" dan tingkat kelayakan 85,44\% atau berada dalam kategori "sangat layak". Dengan demikian, buku ajar IPA kelas VI $\mathrm{SD} / \mathrm{MI}$ semester 1 yang dikembangkan ini dianggap layak digunakan sebagai buku penunjang pada proses pembelajaran.

Hasil penelitian ini sesuai dengan hasil penelitian Rusilowati dkk. (2016) dan Budiningsih dkk. (2015). Buku ajar yang dikembangkan efektif untuk meningkatkan kemampuan literasi sains. Efektivitas buku teks sains yang dikembangkan diklasifikasikan sebagai stimulan yang efektif untuk meningkatkan literasi sains siswa. Itu ditunjukkan pada skor gain dan skor posttest kelompok eksperimen yang mana buku teks sains berdasarkan literasi sains, yang lebih tinggi dari kelompok kontrol memperoleh skor dan skor posttest. Keduanya menunjukkan ilmu yang dikembangkan buku teks layak, dapat dibaca, danefektif.

\section{Simpulan}

Penggunaan buku ajar IPA kelas 6 di SDN Sambungrejo memiliki keterbatasan jumlah. Buku ajar yang digunakan oleh siswa dan guru hanya ada satu jenis buku Buku Sekolah Elektronik (BSE). Selain itu di sekolah juga ada buku Lembar Kerja Siswa (LKS) yang isinya soalsoal tanpa ada bahasan sebelumnya, sehingga siswa kesulitan dalam mengerjakan karena kekurangan sumber belajar

Produk pengembangan yang dihasilkan berupa Buku Ajar IPA ini telah melewati tahapan-tahapan pengembangan yang mengikuti pola pengembangan produk Dick and Carey (2009) dengan terlebih dahulu menganalisis kebutuhan dasar siswa dalam penyediaan buku ajar.

Tingkat kelayakan buku ajar IPA kelas VI SD semester 1 dilihat dari penilaian dosen ahli materi, pengawas sekolah, kepala sekolah, guru kelas VI dan penilaian siswa berdasarkan rata rata masing-masing aspek penilaian meliputi: aspek kelayakan isi didapatkan ratarata 4,086 berkategori "baik" dengan tingkat kelayakan 81,7\%; aspek kelayakan penyajian mendapatkan 
skor rata-rata 4,307 berkategori “ sangat baik" dengan tingkat kelayakan 86,1\%; pada aspek kelayakan bahasa, memperoleh rata-rata skor 4,388 berkategori "sangat baik" dengan tingkat kelayakan 87,75\%; sedangkan pada aspek kegrafikan diperoleh rata-rata skor 4,302 dengan kategori "sangat baik" dengan tingkat kelayakan 86\%. Berdasarkan hasil penelitian secara keseluruhan, buku ajar IPA Kelas 6 SD semester 1 secara keseluruhan memperoleh rata-rata skor 4,271 dengan kategori "baik" dan tingkat kelayakan 85,54\%. Dengan demikian, buku dinyatakan layakdigunakan.

\section{Daftar Rujukan}

Ahmad Rohani. 1997. Media intruksional Edukatif . Jakarta: PT Rineka Cipta.

BPSDMP-PMP. 2012. Pedoman Penulisan Buku Ajar Peningkatan Kompetensi Pendidik. Jakarta: BPSDMP-PMP.

Depdiknas. 2003. Undang-undang RI No.20 tahun 2003 tentang sistem pendidikan nasional. Jakarta: Depdiknas.

Depdiknas. 2006. KTSP untuk Satuan Pendidikan Dasar SD/MI Semester I dan II. Jakarta: CV Cipta Jaya.

Dick. W, Carey. L. Carey. J.O. 2001. The Systematic Design of Instruction. Addison-Wesley Educational Publisher Inc.

Fauziyah, U. 2015. Desain Penelitian Pengembangan Bahan Ajar IPA Terpadu Tema Cahaya dan Warna untuk Pembelajaran IPA SMP. Prosiding Simposium Nasional Inovasi dan Pembelajaran Sains 2015 (SNIPS 2015) 8 dan 9 Juni 2015, Bandung, Indonesia.

Fitriyani, Y, \& Indriyeni. 2017. Development of Problem-Based Teaching Materials for The Fifth Graders of Primary School. JURNAL TA’DIB, 20 (2), 99-107.

Hamalik. 1994. Media Pendidikan. Bandung: Citra Aditya Bakti.

Loveridge, A.J., dkk. 1987. Persiapan Naskah Buku Pelajaran: Pembimbing Bagi Pengarang di Negara- negara Berkembang. Terj. Hasan Amin. Jakarta: Balai Pustaka.

Mintowati. 2003. Panduan Penulisan Buku Ajar. Jakarta: Depdikbud.

Muslich, M. 2010. Textbook Writing: Dasar-dasar Pemahaman Penulisan, dan Pemakaian Buku Teks. Malang: Ar-ruzzmedia.

Nurgiyantoro, B. 2013. Penilaian Pembelajaran Bahasa Berbasis Kompetensi. Yogyakarta: Badan Percetakan Fakultas Ekonomi Universitas Negeri Yogyakarta.

Nurgiyantoro,B. 2016. MetodePenelitianKuantitatif, KualitatifdanR\&D. Bandung:PTAlfabet. Prastowo, A. 2012. Panduan Kreatif Membuat Bahan Ajar Inovatif. Jogjakarta: DIVA Press. 
Pratiwi, I. 2016. Pengembangan Buku Ajar IPA Berbasis Contextual Teaching Learning Untuk Pemecahan Masalah Peserta Didik Kelas IV Sekolah Dasar. Tesis tidak dipublikasikan. Universitas Negeri Semarang.

Pusat Perbukuan Depdiknas. 2006. Pedoman Penulisan Buku Ajar. Jakarta: Pusat Perbukuan Depdiknas.

Sakri, A. 2008. Cara Menulis Buku Ajar. Bandung: ITB.

Samatowa, U. 2006. Bagaimana Membelajarkan IPA di Sekolah Dasar. Jakarta: Direktorat Pendidikan Nasional.

Sukreni, P. 2014. Pengembangan Buku Ajar Pendidikan IPA Kelas IV Semester I SD No. 4 Kaliuntu Dengan Model Dick and Carey. Jurnal Pendidikan Indonesia, 3 (1). 386-397.

Sumaji. 2006. Pendidikan Sains yang Humanis. Jogjakarta: Kanisius IKAPI

Gronlund, N.E. \& Linn, R.L. (1990). Measurement and evaluation in teaching. (6thed.). New York: Macmillan. 